\title{
Emendation of the Genus Planococcus and Transfer of Flavobacterium okeanokoites Zobell and Upham 1944 to the Genus Planococcus as Planococcus okeanokoites comb. nov.
}

\author{
YASUYOSHI NAKAGAWA,* TAKESHI SAKANE, AND AKIRA YOKOTA $\dagger$ \\ Institute for Fermentation, Osaka, Yodogawa-ku, Osaka 532, Japan
}

\begin{abstract}
The taxonomic position of Flavobacterium okeanokoites IFO $12536^{\mathrm{T}}$ ( $\mathrm{T}=$ type strain) was determined by $16 \mathrm{~S}$ rRNA gene sequencing and chemotaxonomic methods. Phylogenetic evidence derived from a 16S rRNA sequence analysis indicated that $F$. okeanokoites, which forms rod-shaped cells, belongs to the genus Planococcus, which forms spherical cells. A phylogenetically close relationship was supported by chemotaxonomic characteristics, such as the presence of menaquinone 7 and menaquinone 8 as major isoprenoid quinones, the presence of phosphatidylglycerol, bisphosphatydylglycerol, and phosphatidylethanolamine as cellular polar lipids, and the G+C content of the DNA $(46.3 \mathrm{~mol} \%)$. These data suggest that whether a cell is a rod or a coccus is not a generic criterion. Accordingly, we propose that $F$. okeanokoites should be transferred to the genus Planococcus and that the description of the genus Planococcus should be emended.
\end{abstract}

Bergey et al. (2) created the genus Flavobacterium for aerobic, yellow-pigmented rods which produce acid from carbohydrates weakly. The original description of this taxon was so vague that it included species that were gram negative, nonmotile or motile by means of flagella, aerobic or facultatively anaerobic, and even gram positive. The heterogeneity of the genus has been reduced by reclassifying various Flavobacterium species into different or new genera $(13,21,29,30)$. Recently, the description of the genus Flavobacterium was emended to restrict it to organisms which contain menaquinone 6 (MK-6) and inhabit soil and freshwater (3), and consequently, the genus Flavobacterium has become a phylogenetically homogeneous group.

Flavobacterium okeanokoites, which was described by Zobell and Upham (32), is one of the misnamed flavobacteria. This organism was isolated from marine mud, and it possesses peritrichous flagella and therefore is treated as a species incertae sedis in Bergey's Manual of Systematic Bacteriology (12). Bauwens and De Ley (1) showed that $F$. okeanokoites did not belong to the genus Flavobacterium on the basis of DNArRNA hybridization results. Chemotaxonomic characteristics suggested that $F$. okeanokoites was similar to the genus Bacillus, even though it could not form spores (28).

We investigated the taxonomic position of $F$. okeanokoites by a polyphasic approach and, on the basis of our results, propose that $F$. okeanokoites should be transferred to the genus Planococcus and that the description of the genus Planococcus should be emended.

\section{MATERIALS AND METHODS}

Bacterial strains and cultivation. The strains examined were $F$. okeanokoites IFO $12536^{\mathrm{T}}\left(=\right.$ NCIMB $\left.561^{\mathrm{T}}\right)\left(\mathrm{T}=\right.$ type strain), Planococcus citreus IAM $12541^{\mathrm{T}}$ $\left(=\right.$ IFO $\left.15849^{\mathrm{T}}\right)$, and Planococcus kocurii IAM $12847^{\mathrm{T}}\left(=\right.$ IFO $\left.15850^{\mathrm{T}}\right)$. The organisms were cultivated aerobically at $28^{\circ} \mathrm{C}$ in medium containing (per liter) $10.0 \mathrm{~g}$ of Polypeptone (Wako Pure Chemical Industries, Osaka, Japan), $2.0 \mathrm{~g}$ of yeast extract (Difco Laboratories, Detroit, Mich.), $1.0 \mathrm{~g}$ of $\mathrm{MgSO}_{4} \cdot 7 \mathrm{H}_{2} \mathrm{O}, 30.0 \mathrm{~g}$ of $\mathrm{NaCl}$, and $15 \mathrm{~g}$ of agar, if needed ( $\mathrm{pH} \mathrm{7.0)}$ ). Cells were harvested by centrifugation at the stationary phase for PCR and chemotaxonomic experiments.

${ }^{*}$ Corresponding author. Mailing address: Institute for Fermentation, Osaka, 17-85, Juso-honmachi 2-chome, Yodogawa-ku, Osaka 532, Japan. Phone: 8163006555 . Fax: 8163006814 .

$\uparrow$ Present address: Institute of Molecular and Cellular Biosciences, The University of Tokyo, Bunkyo-ku, Tokyo 113, Japan.
Morphological and physiological tests. Cells in the early exponential growth phase grown on solid media were used for morphological and physiological characterizations. The size, shape, and motility of cells were determined with a phase-contrast microscope and a scanning electron microscope (model JSM5400; JEOL, Akishima, Japan). The samples used for scanning electron microscopy were prepared by the methods of Yokota et al. (31). Physiological tests were performed as described by Cowan and Steel (6). The ability to form spores was determined by using Schaeffer's medium (25) and soil extract agar, which contains $5.0 \mathrm{~g}$ of peptone (Difco), $3.0 \mathrm{~g}$ of beef extract (Difco), and $15 \mathrm{~g}$ of agar in $750 \mathrm{ml}$ of tap water and $250 \mathrm{ml}$ of soil extract.

Respiratory quinone analysis. Isoprenoid quinones were extracted from freeze-dried cells $(200 \mathrm{mg})$ with chloroform-methanol $(2: 1, \mathrm{vol} / \mathrm{vol})$ and were purified by thin-layer chromatography with $n$-hexane-diethyl ether $(85: 15$, vol vol) as the solvent. The menaquinone fraction was extracted with acetone, dried under a nitrogen gas stream, and then analyzed by high-performance liquid chromatography (HPLC) with a model LC-5A apparatus (Shimadzu, Kyoto, Japan), using a Zorbax octyldecyl silane column (4.6 by $150 \mathrm{~mm}$ ).

Cellular fatty acid analysis. The procedures used to prepare cellular fatty acid methyl esters were the procedures described by Suzuki and Komagata (27). The fatty acid methyl ester composition was determined by gas chromatography-mass spectrometry with a model GC-17A, QP-5000 apparatus (Shimadzu).

Polar lipid analysis. Free lipids were extracted from $100 \mathrm{mg}$ of dried cells,

TABLE 1. Phenotypic characteristics of $F$. okeanokoites IFO $12536^{\mathrm{T}}$

\begin{tabular}{|c|c|}
\hline Characteristic & Strain IFO $12536^{\mathrm{T}}$ \\
\hline \multirow{2}{*}{\multicolumn{2}{|c|}{ Color of colonies }} \\
\hline & Morphology of cells \\
\hline \multicolumn{2}{|c|}{ Gram stain reaction ................................................................ } \\
\hline \multicolumn{2}{|c|}{ Spore formation ..........................................................- } \\
\hline \multicolumn{2}{|c|}{ Catalase activity ....................................................... } \\
\hline \multicolumn{2}{|c|}{ 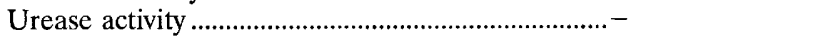 } \\
\hline \multicolumn{2}{|c|}{ Nitrate reduction } \\
\hline \multicolumn{2}{|l|}{ Hydrolysis of: } \\
\hline \multicolumn{2}{|c|}{ Starch } \\
\hline \multicolumn{2}{|c|}{ Esculin } \\
\hline \multicolumn{2}{|c|}{ Tween 80} \\
\hline \multicolumn{2}{|c|}{ Acid production from: } \\
\hline \multicolumn{2}{|c|}{ L-Arabinose } \\
\hline \multicolumn{2}{|c|}{ 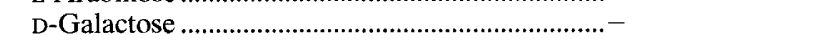 } \\
\hline \multicolumn{2}{|c|}{ 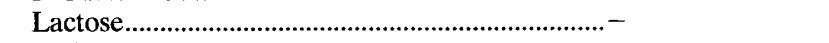 } \\
\hline \multicolumn{2}{|c|}{ Maltose } \\
\hline \multicolumn{2}{|c|}{ 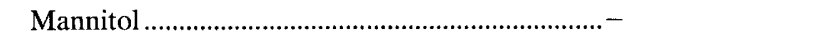 } \\
\hline \multicolumn{2}{|c|}{ Sucrose } \\
\hline \multicolumn{2}{|c|}{ D-Xylose } \\
\hline \multicolumn{2}{|c|}{ Decarboxylation of: } \\
\hline L-Lysine...................... & ...t \\
\hline L-Ornithine........ & \\
\hline
\end{tabular}



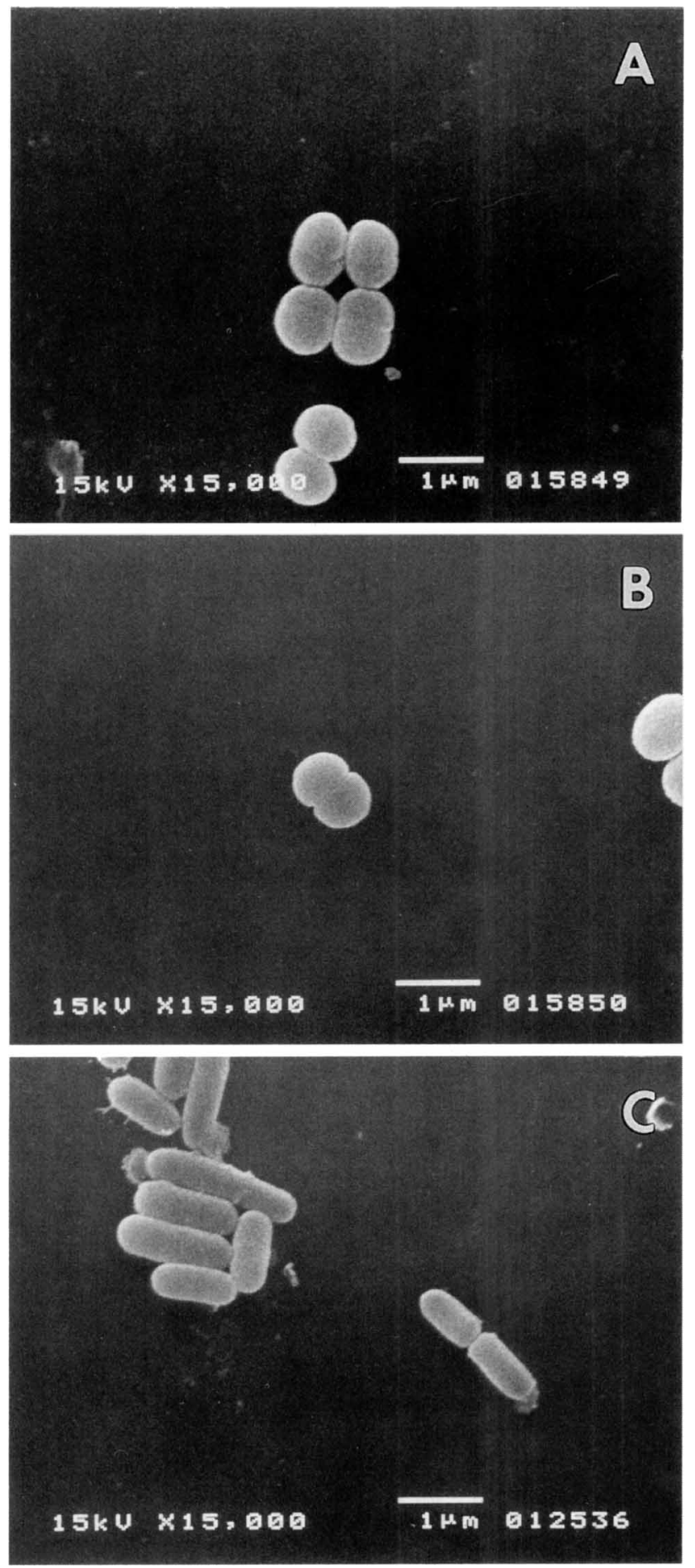

FIG. 1. Scanning electron micrographs of cells of $P$. citreus IAM $12541^{\mathrm{T}}$ $\left(=\right.$ IFO $\left.15849^{\mathrm{T}}\right)(\mathrm{A}), P$. kocurii IAM $12847^{\mathrm{T}}\left(=\mathrm{IFO} 15850^{\mathrm{T}}\right)(\mathrm{B})$, and $F$. okeanokoites IFO $12536^{\mathrm{T}}(\mathrm{C})$.

purified by the procedure of Minnikin et al. (19), and examined by two-dimensional thin-layer chromatography, using Kieselgel $60 \mathrm{~F}_{254}$ plates (E. Merck, Darmstadt, Germany) as described by Yokota et al. (31).

Peptidoglycan analysis. Cell walls were prepared from $500 \mathrm{mg}$ of dried cells by mechanical disruption with a model 201M ultrasonic oscillator (Kubota, Tokyo, Japan) and were purified as described by Schleifer and Kandler (26). The amino acids in complete cell wall hydrolysates were determined as their phenylthiocarbamoyl derivatives by HPLC by using a model LC-6AD apparatus (Shimadzu) and a Wakopak WS-PTC column (Wako Pure Chemical Industries) as recommended by the column manufacturer.

DNA base composition analysis. DNA was extracted by the methods of Marmur (17) and Saito and Miura (23) with the modifications described previously (20). The guanine-plus-cytosine $(\mathrm{G}+\mathrm{C})$ content of the DNA was determined by the method of Mesbah et al. (18).

DNA-DNA hybridization. Levels of DNA relatedness were determined by the photobiotin-microplate method of Ezaki et al. (7).

PCR amplification, cloning, and sequencing of 16S ribosomal DNA. The 16S rRNA gene was amplified by PCR (22) by using TaKaRa Taq (Takara Shuzo, Kyoto, Japan) and primers $9 F$ and $1541 \mathrm{R}(20)$. The $1.5-\mathrm{kb}$ amplified $16 \mathrm{~S}$ ribosomal DNA fragment was purified by agarose gel electrophoresis and with a Prep-A-Gene DNA purification kit (Bio-Rad Laboratories, Hercules, Calif.). The methods used for cloning and sequencing of the purified fragment have been described previously in detail $(20)$. The $5^{\prime}$-fluorescein-labeled oligonucleotide primers used were M13 Universal and Reverse Primer (Pharmacia), as well as primers 339F ( $5^{\prime}$-CTCCTACGGGAGGCAGCAG; same sequence as positions 339 to 357 [Escherichia coli numbering system]), 785F (5'-GGATTAGATACC CTGGTAGTC; same sequence as positions 785 to 805$), 1099 \mathrm{~F}$ (5'-GCAACG AGCGCAACCC; same sequence as positions 1099 to 1115), 536R (5'-GTATT ACCGCGGCTGCTG; complementary to positions 519 to 536), 802R ( $5^{\prime}$-TAC CAGGGTATCTAATCC; complementary to positions 785 to 802 ), and $1115 \mathrm{R}$ (5'-AGGGTTGCGCTCGTTG; complementary to positions 1100 to 1115 ).

Phylogenetic analysis. The 16S rRNA sequences of the strains examined and the sequences of reference organisms obtained from databases were aligned with the $E$. coli sequence (4) (for the accession numbers of the strains see Table 4). The CLUSTAL V software package (11) was used to generate evolutionary distances $\left(K_{\text {nuc }}\right.$ values [14]) and similarity values and to construct a phylogenetic tree by using the neighbor-joining method (24) and the $K_{\text {nuc }}$ values. The positions at which secondary structures varied between strains (positions 66 to 103 179 to 220,447 to 487,841 to 845,1004 to 1036,1134 to 1140 , and 1256 to 1281 ) and the positions at which sequences were not determined in some reference organisms (positions 1431 to 1491) were excluded from the analysis. The total number of nucleotides compared was 1,136 after we eliminated all sites at which sequences were not determined in any organisms. The topology of the phylogenetic tree was evaluated by the bootstrap resampling method of Felsenstein (8) with 1,000 replicates.

Nucleotide sequence accession number. The $16 \mathrm{~S}$ ribosomal DNA sequence of F. okeanokoites IFO $12536^{\mathrm{T}}$ has been deposited in the DDBJ, EMBL, GSDB, and NCBI nucleotide sequence databases under accession number D55729.

\section{RESULTS}

Morphological and physiological characteristics. $F$. okeanokoites IFO $12536^{\mathrm{T}}$ was a gram-positive to gram-variable rodshaped organism whose cells were 0.4 to $0.8 \mu \mathrm{m}$ wide and 1.0 to $20 \mu \mathrm{m}$ long (Fig. 1). Most cells were less than $2.8 \mu \mathrm{m}$ long. Motile cells were observed in the early growth phase, and these

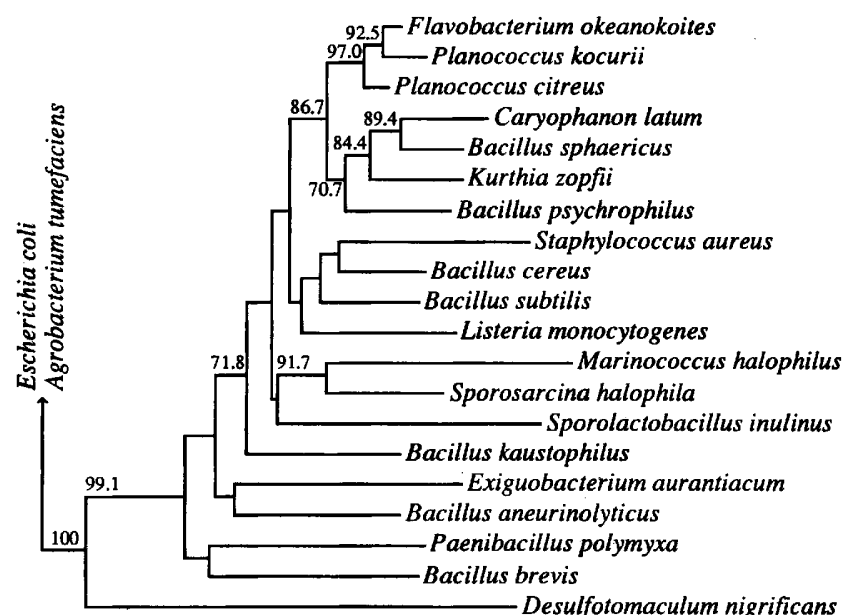

$0.01 K_{\text {nuc }}$

FIG. 2. Phylogenetic tree derived from 16S rRNA sequences of $F$. okeanokoites and related organisms. E. coli and Agrobacterium tumefaciens were used as the root organisms. Scale bar $=0.01 K_{\text {nuc }}$ in nucleotide sequences. The lengths of the vertical lines are not significant. The numbers on the branches are the confidence limits (expressed as percentages) estimated by a bootstrap analysis performed with 1,000 replicates. Confidence limits less than $60 \%$ are not shown. 
TABLE 2. Differential properties of $F$. okeanokoites and Planococcus species ${ }^{a}$

\begin{tabular}{|c|c|c|c|c|c|c|c|c|c|}
\hline \multirow{2}{*}{ Species } & \multicolumn{2}{|c|}{$\begin{array}{l}\text { Growth in the } \\
\text { presence of: }\end{array}$} & \multirow{2}{*}{$\begin{array}{r}\text { Oxidase } \\
\text { activity }\end{array}$} & \multirow{2}{*}{$\begin{array}{l}\text { Hydrolysis } \\
\text { of gelatin }\end{array}$} & \multirow{2}{*}{$\begin{array}{l}\text { Acid produced } \\
\text { from glucose }\end{array}$} & \multirow{2}{*}{$\begin{array}{c}\text { Major } \\
\text { menaquinones }\end{array}$} & \multirow{2}{*}{$\begin{array}{l}\text { Major fatty } \\
\text { acid(s) }{ }^{b}\end{array}$} & \multirow[t]{2}{*}{ Phospholipids $^{c}$} & \multirow{2}{*}{$\begin{array}{c}\mathrm{G}+\mathrm{C} \text { content } \\
\text { of DNA } \\
(\mathrm{mol} \%)\end{array}$} \\
\hline & No $\mathrm{NaCl}$ & $15 \% \mathrm{NaCl}$ & & & & & & & \\
\hline$P$. citreus & $+^{d}$ & + & - & + & + & MK-7, MK-8 & ai15:0 & PE, PG, BPG & $48-52$ \\
\hline P. kocurii & + & - & - & + or - & + & MK-7, MK-8 & ai15:0 & PE, PG, BPG & $39-43$ \\
\hline F. okeanokoites & w & - & w & + & - & MK-8, MK-7 & $\mathrm{i} 14: 0, \mathrm{i} 16: 0$ & $\mathrm{PE}, \mathrm{PG}, \mathrm{BPG}$ & 46.3 \\
\hline
\end{tabular}

${ }^{a}$ Data from reference 10 and this study.

${ }^{b} \mathrm{i}$, iso branched; ai, anteiso branched; 14:0, tetradecanoic acid; 15:0, pentadecanoic acid; 16:0, hexadecanoic acid.

${ }^{c}$ PE, phosphatidylethanolamine; PG, phosphatidylglycerol; BPG, bisphosphatidylglycerol.

${ }^{d}+$, positive; - , negative; $w$, weakly positive.

cells had peritrichous flagella (data not shown). Spore-forming cells were not observed in any medium. Some of the phenotypic characteristics of IFO $12536^{\mathbf{T}}$ are shown in Tables 1 and 2.

Chemotaxonomic characteristics. Some chemotaxonomic characteristics of $F$. okeanokoites IFO $12536^{\mathbf{T}}$ are summarized in Table 2. The major isoprenoid quinones of this organism were MK-7 and MK-8, which accounted for 34 and $66 \%$ of the total isoprenoid quinones, respectively. The cellular fatty acids were mainly branched fatty acids. IFO $12536^{\mathbf{T}}$ contained isotetradecanoic acid (i14:0) (33.9\% of the total fatty acids) and iso-hexadecanoic acid (i16:0) (28.1\%) as its major cellular fatty acids (Table 3). The cellular polar lipids of IFO $12536^{\mathrm{T}}$ were phosphatidylglycerol, bisphosphatydylglycerol, and phosphatidylethanolamine. The molar ratio of the amino acids glutamic acid, lysine, alanine, and aspartic acid in the cell wall was $1: 1: 2: 1$. No attempt was made to determine the chiral nature of the amino acids.

16S rRNA sequence analysis. The 16S rRNA sequence of $F$. okeanokoites IFO $12536^{\mathrm{T}}$ was determined from position 29 to position 1491 . The levels of 16S rRNA similarity are shown in Table 4 . The phylogenetic tree constructed by the neighborjoining method and the $K_{\text {nuc }}$ values shows that $F$. okeanokoites IFO $12536^{\mathrm{T}}$ should be included in the genus Planococcus (the similarity values range from 98.6 to $99.0 \%$ ) (Fig. 2 and Table 4).

DNA-DNA hybridization. The results of DNA-DNA hybridization experiments performed with $F$. okeanokoites IFO $12536^{\mathrm{T}}, P$. citreus IAM $12541^{\mathrm{T}}$, and $P$. kocurii IAM $12847^{\mathrm{T}}$ are shown in Table 5. F. okeanokoites IFO $12536^{\mathrm{T}}$ did not exhibit species level DNA relatedness (i.e., $>70 \%$ relatedness) with any of the other species examined.

\section{DISCUSSION}

Cellular morphology has been used as a key feature to define genera. However, our phylogenetic analysis clearly revealed that $F$. okeanokoites, which forms rod-shaped cells but not coccoid cells, belongs to the genus Planococcus, which forms spherical cells (Fig. 1 and 2). A phylogenetic jumble of cocci and rods has been observed in the genera Bacillus and Staphylococcus (5), the genera Clostridium and Sarcina (5), and the genera Arthrobacter and Micrococcus $(15,16)$. Koch et al. (16) proposed that Micrococcus agilis should be transferred to the genus Arthrobacter and that the description of the genus $A r$ throbacter should be emended to include species which form spherical cells. F. okeanokoites and the genus Planococcus share the following chemotaxonomic characteristics: MK-7 and MK-8 are the major isoprenoid quinones, phosphatidylethanolamine, phosphatidylglycerol, and bisphosphatidylglycerol are the cellular polar lipids, and branched fatty acids are the major cellular fatty acids (Tables 2 and 3 ). The $\mathrm{G}+\mathrm{C}$ content of the DNA of $F$. okeanokoites IFO $12536^{\mathrm{T}}(46.3 \mathrm{~mol} \%)$ is also similar to the $\mathrm{G}+\mathrm{C}$ contents of members of the genus Planococcus (Table 2).

Levels of DNA relatedness of 15 to $27 \%$ for $F$. okeanokoites IFO $12536^{\mathrm{T}}, P$. citreus IAM $12541^{\mathrm{T}}$, and $P$. kocurii IAM $12847^{\mathrm{T}}$ indicate that these organisms belong to different species (Table 5). $F$. okeanokoites can also be differentiated from $P$. citreus and $P$. kocurii phenotypically (Table 2 ). $F$. okeanokoites IFO $12536^{\mathrm{T}}$ is characterized by having i14:0 and i16:0 as its major cellular fatty acids, whereas Planococcus species are characterized by having anteiso-pentadecanoic acid (ai15:0). F. okeanokoites IFO $12536^{\mathrm{T}}$ contains aspartic acid in the peptidoglycan of its cell walls, and this compound is not found in Planococcus species (10). Accordingly, we propose that $F$. okeanokoites should be transferred to the genus Planococcus as Planococcus okeanokoites comb. nov. A description of Planococcus okeanokoites is given below. The transfer of a rod-shaped species to the genus Planococcus means that the description of this genus must also be emended, as described below.

Emended description of the genus Planococcus Migula 1894. Cells are cocci that are 1.0 to $1.2 \mu \mathrm{m}$ in diameter and occur singly, in pairs, in threes, or in tetrads or are rods which are 0.4 to $0.8 \mu \mathrm{m}$ wide and 1.0 to $20 \mu \mathrm{m}$ long. Gram positive to gram variable. Motile. Motile cells possess several flagella. Spores are not formed. The color of the cell mass is yellow to orange. Chemoorganotrophs. Metabolism is respiratory. Aerobes. Catalase positive. Urease negative. Nitrate is not reduced to nitrite. Hydrolysis of esculin, starch, and Tween 80 is negative. The

TABLE 3. Cellular fatty acid compositions of F. okeanokoites and Planococcus species

\begin{tabular}{|c|c|c|c|c|c|c|c|c|c|c|c|c|c|c|c|c|}
\hline \multirow{2}{*}{ Strain } & \multicolumn{16}{|c|}{ Fatty acid composition $(\%)^{a}$} \\
\hline & $\mathrm{i} 14: 0$ & $14: 0$ & i15:0 & ai15:0 & $15: 0$ & $15: 1$ & i16:0 & i16:1 & $16: 0$ & $16: 1$ & i17:0 & ai17:0 & $17: 0$ & $17: 1$ & i18:0 & 18:0 \\
\hline P. citreus IAM $12541^{\mathrm{T}}$ & 3.4 & $\operatorname{Tr}^{b}$ & 1.5 & 59.0 & 5.0 & $\operatorname{Tr}$ & 5.9 & 4.7 & 3.7 & 4.1 & & 10.9 & 5.5 & 3.2 & $\operatorname{Tr}$ & 1.7 \\
\hline P. kocurii IAM $12847^{\mathrm{T}}$ & 11.9 & $\operatorname{Tr}$ & 4.3 & 48.7 & 13.5 & 4.1 & 4.0 & 6.7 & 2.7 & 2.9 & & 3.1 & $\operatorname{Tr}$ & $\operatorname{Tr}$ & & 2.2 \\
\hline F. okeanokoites IFO $12536^{\mathrm{T}}$ & 33.9 & $\mathrm{Tr}$ & 2.9 & 14.0 & $\operatorname{Tr}$ & & 28.1 & 11.7 & 4.7 & 2.8 & $\operatorname{Tr}$ & $\operatorname{Tr}$ & & & $\operatorname{Tr}$ & 1.8 \\
\hline
\end{tabular}

\footnotetext{
${ }^{a} \mathrm{i}$, iso branched; ai, anteiso branched.
}

$b$ Tr, trace (less than $1 \%$ ). 
TABLE 4. Similarity matrix for $16 \mathrm{~S}$ rRNA sequences of $F$. okeanokoites and related organisms

\begin{tabular}{|c|c|c|c|c|c|c|c|c|c|c|c|c|c|c|c|c|c|c|}
\hline \multirow[b]{2}{*}{ Organism } & \multirow[b]{2}{*}{$\begin{array}{c}\text { Accession } \\
\text { no. }\end{array}$} & \multicolumn{17}{|c|}{$\%$ Similarity } \\
\hline & & 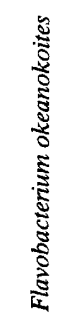 & 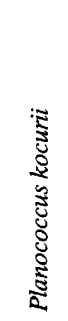 & 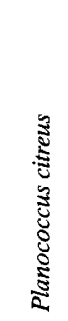 & 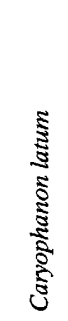 & 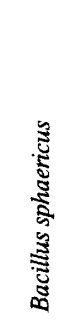 & 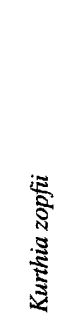 & 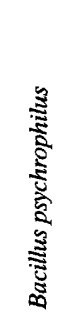 & 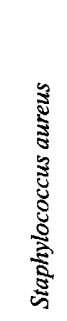 & 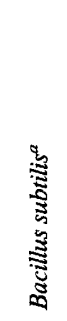 & 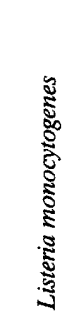 & 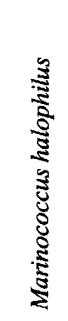 & 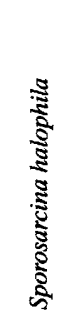 & 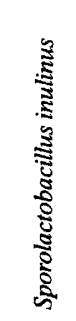 & 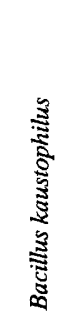 & 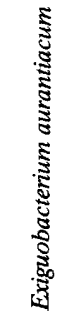 & 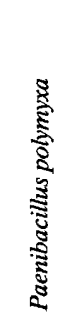 & 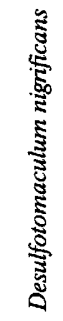 \\
\hline Planococcus kocurii & X62173 & 99.0 & & & & & & & & & & & & & & & & \\
\hline Planococcus citreus & X62172 & 99.0 & 98.6 & & & & & & & & & & & & & & & \\
\hline Caryophanon latum & X70314 & 96.0 & 96.0 & 96.3 & & & & & & & & & & & & & & \\
\hline Bacillus sphaericus & D16280 & 96.7 & 96.1 & 96.7 & 97.7 & & & & & & & & & & & & & \\
\hline Kurthia zopfii & X70321 & 96.8 & 96.5 & 96.3 & 96.8 & 97.0 & & & & & & & & & & & & \\
\hline Bacillus psychrophilus & D16277 & 97.4 & 97.1 & 97.1 & 96.2 & 96.4 & 96.7 & & & & & & & & & & & \\
\hline Staphylococcus aureus & L37597 & 94.3 & 94.1 & 94.5 & 93.5 & 94.4 & 94.2 & 93.9 & & & & & & & & & & \\
\hline Bacillus subtilis & & 96.0 & 95.7 & 96.5 & 95.0 & 95.4 & 94.7 & 95.1 & 95.3 & & & & & & & & & \\
\hline Listeria monocytogenes & S55472 & 95.8 & 95.3 & 96.0 & 94.1 & 94.7 & 94.9 & 95.1 & 94.6 & 95.7 & & & & & & & & \\
\hline Marinococcus halophilus & X62171 & 93.5 & 93.3 & 93.7 & 91.6 & 92.7 & 92.3 & 92.7 & 91.3 & 93.1 & 92.3 & & & & & & & \\
\hline Sporosarcina halophila & X62175 & 95.3 & 95.1 & 95.8 & 93.6 & 93.8 & 93.8 & 94.7 & 93.3 & 95.3 & 95.0 & 94.4 & & & & & & \\
\hline Sporolactobacillus inulinus & D16283 & 93.7 & 93.3 & 94.1 & 92.1 & 92.4 & 93.1 & 93.1 & 92.0 & 93.9 & 93.4 & 91.7 & 93.1 & & & & & \\
\hline Bacillus kaustophilus & X60618 & 95.7 & 95.2 & 95.9 & 94.1 & 94.7 & 93.8 & 94.5 & 92.7 & 94.9 & 94.1 & 92.3 & 94.4 & 93.1 & & & & \\
\hline Exiguobacterium aurantiacum & X70316 & 93.8 & 93.2 & 93.6 & 93.4 & 93.1 & 93.3 & 93.1 & 91.6 & 92.8 & 92.2 & 90.7 & 92.4 & 91.2 & 93.1 & & & \\
\hline Paenibacillus polymyxa & D16276 & 93.3 & 93.1 & 93.3 & 92.3 & 92.6 & 92.3 & 92.7 & 91.2 & 92.0 & 91.2 & 91.5 & 92.3 & 91.9 & 92.6 & 91.7 & & \\
\hline Desulfotomaculum nigrificans & X62176 & 88.7 & 88.4 & 89.0 & 89.2 & 89.0 & 87.9 & 87.9 & 87.7 & 88.3 & 87.6 & 87.2 & 87.9 & 86.2 & 89.7 & 87.6 & 88.8 & \\
\hline Escherichia coli ${ }^{b}$ & & 82.8 & 82.4 & 82.4 & 82.7 & 82.6 & 83.0 & 83.6 & 82.5 & 82.6 & 82.8 & 81.8 & 83.0 & 82.7 & 83.8 & 82.6 & 83.3 & 82.3 \\
\hline
\end{tabular}

\footnotetext{
${ }^{a}$ Data from reference 9
}

${ }^{b}$ Data from reference 4 .

major isoprenoid quinones are MK-7 and MK-8. The cellular fatty acids are mainly branched fatty acids. The $\mathrm{G}+\mathrm{C}$ content of the DNA is 39 to $52 \mathrm{~mol} \%$.

Description of Planococcus okeanokoites comb. nov. Planococcus okeanokoites (o.ke.a.no.ko.i'tes. Gr. masc. n. oceanus, the ocean; Gr. fem. n. coites, bed; M.L. fem. gen. n. okeanokoites, of the ocean bed). Cells are rods that are 0.4 to $0.8 \mu \mathrm{m}$ wide and 1.0 to $20 \mu \mathrm{m}$ long. Most cells are less than $2.8 \mu \mathrm{m}$ long. Motile cells have peritrichous flagella. Spores are not formed. Gram positive to gram variable in medium containing $\mathrm{NaCl}$. Gram negative in medium without $\mathrm{NaCl}$. The color of the cell mass is usually bright yellow to bright orange. Chemoorganotrophs. Metabolism is respiratory. Strict aerobes. Catalase positive. Weakly oxidase positive. Urease negative. Nitrate is not reduced to nitrite. The following tests are positive: arginine dihydrolase, lysine decarboxylase, ornithine decarboxylase, decomposition of casein, and liquefaction of gelatin. The following tests are negative: methyl red; Voges-Proskauer reaction; indole production; phenylalanine deaminase; hydrolysis of starch and cellulose; and decomposition of tyrosine, esculin, and Tween 80. Acid is not produced from D-glucose, D-galactose, L-arabinose, D-xylose, sucrose, maltose, lactose, or man-

TABLE 5. Levels of DNA relatedness for $F$. okeanokoites and Planococcus strains

\begin{tabular}{|c|c|c|c|}
\hline \multirow{2}{*}{ Strain } & \multicolumn{3}{|c|}{$\%$ Reassociation with DNA from: } \\
\hline & IAM $12541^{\mathrm{T}}$ & IAM $12847^{\mathrm{T}}$ & IFO $12536^{\mathrm{T}}$ \\
\hline P. citreus IAM $12541^{\mathrm{T}}$ & 100 & 22 & 27 \\
\hline P. kocurii IAM $12847^{\mathrm{T}}$ & 16 & 100 & 22 \\
\hline F. okeanokoites IFO $12536^{\mathrm{T}}$ & 15 & 26 & 100 \\
\hline
\end{tabular}

nitol in Hugh-Leifson O-F medium. The optimum level of salinity for growth is 3 to $5 \% \mathrm{NaCl}$. No growth occurs in the presence of more than $7 \% \mathrm{NaCl}$. The optimum growth temperature is 20 to $37^{\circ} \mathrm{C}$.

The molar ratio of the amino acids glutamic acid, lysine, alanine, and aspartic acid in the cell wall is $1: 1: 2: 1$. The major isoprenoid quinones are MK-8 and MK-7. The major cellular fatty acids are i14:0 and i16:0. The $\mathrm{G}+\mathrm{C}$ content of the DNA of the type strain is $46.3 \mathrm{~mol} \%$.

The type strain is IFO 12536 (= NCIMB 561).

\section{ACKNOWLEDGMENTS}

We are grateful to the IAM Culture Collection, Institute of Molecular and Cellular Biosciences, The University of Tokyo, Tokyo, Japan, and The National Collections of Industrial and Marine Bacteria, Ltd., Aberdeen, United Kingdom, for kindly supplying bacterial cultures. We also thank Tomohiko Tamura of the Institute for Fermentation, Osaka for help with scanning electron microscopy.

\section{REFERENCES}

1. Bauwens, M., and J. De Ley. 1981. Improvements in the taxonomy of Flavobacterium by DNA:rRNA hybridizations, p. 27-31. In $\mathrm{H}$. Reichenbach and O. B. Weeks (ed.), The Flavobacterium-Cytophaga group. Verlag Chemie, Weinheim, Germany.

2. Bergey, D. H., F. C. Harrison, R. S. Breed, B. W. Hammer, and F. M. Huntoon. 1923. Genus II. Flavobacterium gen. nov., p. 97-111. In Bergey's manual of determinative bacteriology. Williams \& Wilkins, Baltimore.

3. Bernardet, J.-F., P. Segers, M. Vancanneyt, F. Berthe, K. Kersters, and P. Vandamme. 1996. Cutting a gordian knot: emended classification and description of the genus Flavobacterium, emended description of the family Flavobacteriaceae, and proposal of Flavobacterium hydatis nom. nov. (basonym, Cytophaga aquatilis Strohl and Tait 1978). Int. J. Syst. Bacteriol. 46:128-148.

4. Brosius, J., M. L. Palmer, P. J. Kennedy, and H. F. Noller. 1978. Complete nucleotide sequence of a 16S ribosomal RNA gene from Escherichia coli. Proc. Natl. Acad. Sci. USA 75:4801-4805. 
5. Collins, M. D., P. A. Lawson, A. Willems, J. J. Cordoba, J. FernandezGarayzabal, P. Garcia, J. Cai, H. Hippe, and J. A. E. Farrow. 1994. The phylogeny of the genus Clostridium: proposal of five new genera and eleven new species combinations. Int. J. Syst. Bacteriol, 44:812-826.

6. Cowan, S. T., and K. J. Steel. 1965. Manual for the identification of medical bacteria. Cambridge University Press, London.

7. Ezaki, T., Y. Hashimoto, and E. Yabuuchi. 1989. Fluorometric deoxyribonucleic acid-deoxyribonucleic acid hybridization in microdilution wells as an alternative to membrane filter hybridization in which radioisotopes are used to determine genetic relatedness among bacterial strains. Int. J. Syst. Bacteriol. 39:224-229.

8. Felsenstein, J. 1985. Confidence limits on phylogenies: an approach using the bootstrap. Evolution 39:783-791.

9. Green, C. J., G. C. Stewart, M. A. Hollis, B. S. Vold, and K. F. Bott. 1985 Nucleotide sequence of Bacillus subtilis ribosomal RNA operon, $r m B$. Gene 37:261-266.

10. Hao, M. V., and K. Komagata. 1985. A new species of Planococcus, P. kocurii isolated from fish, frozen foods, and fish curing brine. J. Gen. Appl. Microbiol. 31:441-455.

11. Higgins, D. G., A. J. Bleasby, and R. Fuchs. 1992. CLUSTAL V: improved software for multiple sequence alignment. Comput. Applic. Biosci. 8:189191.

12. Holmes, B., R. J. Owen, and T. A. McMeekin. 1984. Genus Flavobacterium, p. 353-361. In N. R. Krieg and J. G. Holt (ed.), Bergey's manual of systematic bacteriology, vol. 1. Williams \& Wilkins, Baltimore.

13. Holmes, B., A. G. Steigerwalt, R. E. Weaver, and D. J. Brenner. 1986 Weeksella virosa gen. nov., sp. nov. (formerly group IIf), found in human clinical specimens. Syst. Appl. Microbiol. 8:185-190.

14. Kimura, M. 1980. A simple method for estimating evolutionary rates of base substitutions through comparative studies of nucleotide sequences. J. Mol. Evol. 16:111-120.

15. Koch, C., F. A. Rainey, and E. Stackebrandt. 1994. 16S rDNA studies on members of Arthrobacter and Micrococcus: an aid for their future taxonomic restructuring. FEMS Microbiol. Lett. 123:167-172.

16. Koch, C., P. Schumann, and E. Stackebrandt. 1995. Reclassification of Micrococcus agilis (Ali-Cohen 1889) to the genus Arthrobacter as Arthrobacter agilis comb. nov. and emendation of the genus Arthrobacter. Int. J. Syst. Bacteriol. 45:837-839.

17. Marmur, J. 1961. A procedure for the isolation of deoxyribonucleic acid from microorganisms. J. Mol. Biol. 3:208-218.

18. Mesbah, M., U. Premachandran, and W. B. Whitman. 1989. Precise measurement of the $\mathrm{G}+\mathrm{C}$ content of deoxyribonucleic acid by high-performance liquid chromatography. Int. J. Syst. Bacteriol. 39:159-167.
19. Minnikin, D. E., M. D. Collins, and M. Goodfellow. 1979. Fatty acid and polar lipid composition in the classification of Cellulomonas, Oerskovia and related taxa. J. Appl. Bacteriol, 47:87-95.

20. Nakagawa, Y., T. Sakane, and A. Yokota. 1996. Transfer of "Pseudomonas riboflavina" (Foster 1944), a gram-negative, motile rod with long-chain 3-hydroxy fatty acids, to Devosia riboflavina gen. nov., sp. nov., nom. rev. Int. J. Syst. Bacteriol. 46:16-22.

21. Reichenbach, H. 1989. Genus 1. Cytophaga, p. 2015-2050. In J. T. Staley, M. P. Bryant, N. Pfennig, and J. G. Holt (ed.), Bergey's manual of systematic bacteriology, vol. 3. Williams \& Wilkins, Baltimore.

22. Saiki, R. K., D. H. Gelfand, S. Stoffel, S. J. Scharf, R. Higuchi, G. T. Horn, K. B. Mullis, and H. A. Erlich. 1988. Primer-directed enzymatic amplification of DNA with a thermostable DNA polymerase. Science 239:487-491.

23. Saito, H., and K. Miura. 1963. Preparation of transforming deoxyribonucleic acid by phenol treatment. Biochim. Biophys. Acta 72:619-629.

24. Saitou, N., and M. Nei. 1987. The neighbor-joining method: a new method for reconstructing phylogenetic trees. Mol. Biol. Evol. 4:406-425.

25. Schaeffer, P., and H. Ionesco. 1960. Contribution à l'étude génétique de la sporogenèse bactérienne. C. R. Acad. Sci. 251:3125-3127.

26. Schleifer, K. H., and O. Kandler. 1972. Peptidoglycan types of bacterial cell walls and their taxonomic implications. Bacteriol. Rev. 36:407-477.

27. Suzuki, K., and K. Komagata. 1983. Taxonomic significance of cellular fatty acid composition in some coryneform bacteria. Int. J. Syst. Bacteriol. 33: 188-200.

28. Takeuchi, M., and A. Yokota. 1991. Reclassification of strains of Flavobacterium-Cytophaga group in IFO culture collection. Inst. Ferment. Res. Commun. (Osaka) 15:83-96.

29. Vandamme, P., J.-F. Bernardet, P. Segers, K. Kersters, and B. Holmes. 1994 New perspectives in the classification of the flavobacteria: description of Chryseobacterium gen. nov., Bergeyella gen. nov., and Empedobacter nom. rev. Int. J. Syst. Bacteriol. 44:827-831.

30. Yabuuchi, E., T. Kaneko, I. Yano, C. W. Moss, and N. Miyoshi. 1983 Sphingobacterium gen. nov., Sphingobacterium spiritivorum comb. nov., Sphingobacterium multivorum comb. nov., Sphingobacterium mizutae sp. nov., and Flavobacterium indologenes sp. nov.: glucose-nonfermenting gram-negative rods in CDC groups IIk-2 and IIb. Int. J. Syst. Bacteriol. 33:580-598.

31. Yokota, A., T. Tamura, T. Hasegawa, and L. H. Huang. 1993. Catenuloplanes japonicus gen. nov., sp. nov., nom. rev., a new genus of the order Actinomycetales. Int. J. Syst. Bacteriol. 43:805-812.

32. Zobell, C. E., and H. C. Upham. 1944. A list of marine bacteria including descriptions of sixty new species. Bull. Scripps Inst. Oceanogr. Univ. Calif. 5:239-292. 